\title{
Z Kuşağının Sosyal Medyaya Yönelik Algılarının Metafor Analizi Yoluyla İncelenmesi
}

\section{Exploring the Perceptions of Generation $\mathrm{Z}$ towards Social Media through Metaphor Analysis}

\author{
Seden DOĞAN, Ondokuz Mayıs Üniversitesi, Türkiye, seden.dogan@omu.edu.tr \\ Orcid No: 0000-0001-8547-7702 \\ İsmail ERKAN, İzmir Katip Çelebi Üniversitesi, Türkiye, ismail.erkan@ikcu.edu.tr \\ Orcid No: 0000-0003-1271-3481
}

\begin{abstract}
Öz: Bu çalışmanın amacı Z kuşağının sosyal medya kavramına yönelik algılarını belirlemektir. Bu amaç doğrultusunda metafor analizine başvurulmuş, turizm fakültesinde lisans eğitimi alan 99 ögrenciden elde edilen veriler incelenmiştir. Analiz sonucunda 53 geçerli metafor tespit edilmiş, bu metaforlardan 19'unun olumlu, 34'ünün olumsuz anlam içerdiği tespit edilmiştir. Olumlu metaforlar arasında en çok kullanılan ifadeler "dünya”, "hayat", "băg" gibi kelimeler iken, olumsuz metaforlar arasında en çok kullanılan ifadelerin "kuyu”, bulaşıcı hastalık", "girdap" gibi kelimelerin olduğu tespit edilmiştir. Çalışmanın sonuçları hem teorik hem de pratik açıdan değerlendirilmiştir.
\end{abstract}

Anahtar Sözcükler: Sosyal Medya, Metafor Analizi, İsletme, Sosyal Medya Pazarlaması, Turizm Öğrencileri

Abstract: The aim of this study is to identify the perceptions of generation Z towards social media concept. With this aim, a metaphor analysis has been applied, and the data obtained from 99 university students who are studying at tourism faculty (bachelor degree). The results show that there are 53 valid metaphors; 19 of these metaphors are considered positive while 34 of them are considered negative. Among the positive metaphors, the most common ones are identified as: "world", "life", "connection". Among the negative metaphors, the most common ones are identified as: "well", "contagious disease", "eddy". Both theoretical and practical implications are discussed.

\section{Keywords: Social Media, Metaphor Analysis, Business, Social Media Marketing, Tourism Students}

\section{Giriș}

Son yıllarda sosyal medyanın giderek yaygınlaşan kullanımı işletmelerin dikkatini çekmiş ve bu platformlar pazarlama aracı olarak kullanılmaya başlanmıştır. İşletmeler artık hedef müşteri kitleleriyle iletişim kurmak ve marka bilinirliğini artırmak gibi amaçlar için sosyal medyayı önemli bir araç olarak görmektedirler (Barutçu ve Tomaş, 2013). Sosyal medyanın her yaştan kullanıcıya ulaşabilme imkanı sunması pazarlama yöneticileri için tüketici araştırmaları gerçekleştirme imkanı da vermektedir. Yöneticiler ürün veya servisleri hakkında olumlu, olumsuz yorumları alabilme ve aldığ1 geribildirimler ile çalışmalarını geliştirme şansı elde etmişlerdir. Bunun yanında, pazarlama yöneticileri sosyal medyayı kullanarak rakipleri hakkında daha detaylı bilgi elde etme firsatını da yakalamıştır. Ancak sosyal medya işletmeler için sadece firsatlar değil aynı zamanda tehditler de oluşturabilmekte, zaman zaman işletmeler hakkındaki negatif bir bilgi hızla yayılabilmektedir. Bu negatif bilgileri önleyebilmek, gerektiğinde açıklama yapabilmek, ya da sorun büyümeden / yayılmadan önleyebilmek için pazarlama yöneticilerinin sosyal medyada yer alması adeta zorunluluk haline gelmiştir. Bu sebeplerle sosyal medya işletmeler için hayli önemli bir konuma gelmiş, sosyal medya yönetimi ve sosyal medyada stratejileri, pazarlama literatüründe yerini almıştır (Barutçu ve Tomaş, 2013).

Öte yandan Z kuşağı olarak tanımlanan, 2000 yılı ve sonrasında doğmuş olan genç tüketicilerin (Çetin ve Karalar, 2016), sosyal medyaya olan yaklaşımlarının diğer kuşaklar ile aynı olup olmadığı merak konusudur. Mevcut araştırmalar X kuşağı tüketiciler (1965-1980 yılları arasında doğmuş olanlar), Y kuşağı tüketiciler (1981-1999 yılları arasında doğmuş olanlar), ve Z kuşağı tüketiciler (2000 yılı ve sonrasında doğmuş olanlar) arasında pazarlama açısından farklılıklar olduğunu ortaya koymaktadır (Sarıtaş ve Barutçu, 2016). Sarıtaş ve Barutçu (2016) çalışmalarında X, Y ve Z kuşaklarını sosyal medya kullanımı açısından karşılaştırmış; "iletişim başlatma, içerik paylaşma ve eğlence” amaçlarında kuşaklar arasında farklılık bulunmazken, "araştırma yapma, işbirliği, iletişimi kurma ve iletişimi sürdürme" amaçlarında kuşakların ayrıştığını tespit etmiştir. Dahası, araştırmacılar Z kuşağının araştırma, işbirliği, iletişimi kurma ve sürdürme amaçlarına X ve Y kuşaklarına göre daha az önem verdiğini saptamışlardır. Bu da pazarlama yöneticilerinin sosyal medya stratejileri belirlerken kuşaklar arasındaki farklılıkları gözetmeleri gerekliliğinin altını çizmektedir. Bu çalışma, bu yüzden, Z kuşağının sosyal medya kavramına yönelik algılarını belirlemeyi amaçlamış, ve bu amaç doğrultusunda üniversite öğrencileri ile bir metafor analizi gerçekleştirmiştir. 


\section{Z Kuşağı ve Sosyal Medya}

Her geçen gün yenilenen teknolojik gelişmeler, farklı yaş grupları üzerinde farklı etkiler oluşturmaktadır. Her kuşağın kendine özgü beklentileri, yaşam tarzları ve değerleri bulunduğundan, teknolojik gelişmelere ve internet üzerindeki yeni platformlara farklı tepkiler vermeleri de kabul edilebilir bir durumdur. Sosyal medya kullanıcılarının sosyal medyayı kullanım motivasyonlarına dair veriler aşağıdaki tabloda yer almaktadır (GlobalWebIndex, 2018; Yücel Güngör, 2018).

Tablo 1. Sosyal Medya Kullanım Motivasyonları

$\begin{array}{ll}\text { Motivasyon } & (\boldsymbol{\%}) \\ \text { Arkadaşlarının ne yaptığını takip etmek } & 41 \\ \text { Haberler ve olayları takip etmek } & 40 \\ \text { Boş zaman değerlendirmek } & 39 \\ \text { Eğlenceli ve komik içerik bulmak } & 37 \\ \text { Diğer insanlarla bağlantı kurmak } & 33 \\ \text { Fotoğraf ve video paylaşmak için } & 32 \\ \text { Pek çok arkadaş sosyal medyada olduğu için } & 32 \\ \text { Satın almak için ürün aramak/araştırmak için } & 30 \\ \text { Görüşlerini paylaşmak için } & 29 \\ \text { Yeni insanlarla tanışmak için } & 27\end{array}$

Teknolojik açıdan oldukça sofistike olarak ifade edilen Z Kuşağı, iletişimi yaşamlarının hayati bir fonksiyonu olarak görmektedirler. Teknolojiyi kimliklerinin bir parçası olarak görmekte ve teknolojinin olmadığı bir dünyayı hayal edemediklerini dile getirmektedirler (Özkan ve Solmaz, 2015; Singh, 2016). Z kuşağı, önceki kuşaklara kıyasla bilgiyi daha hızlı yorumlayabilmektedir (Çetin ve Karalar, 2016). Diğer kuşaklara göre hızı daha çok seven Z kuşağı, çoklu görev yapabilme (multi-tasking) konusunda oldukça başarılıdır ve bu başarıyı günlük işlerinde rahatça kullanabilmektedirler (Golovinski, 2011). Hatta birden fazla işi aynı anda yapabilmeleri nedeniyle (çoklu görev / multi-tasking) bu neslin el, göz ve kulak becerilerinin çok gelişmiş olduğu ve bunun gelecekte daha çok gözlemleneceği tahmin edilmektedir (Berkup, 2014; Çetin ve Karalar, 2016). Dikkat süreleri oldukça kısa olduğu için (sadece birkaç saniye) onların dikkati çekmek için görsel içeriklerin kullanılması tavsiye edilmektedir (Artemova, 2018). Bu durum sosyal medya kullanımındaki beklentileri de etkilemektedir.

Z Kuşağı temsilcilerinin \%91'i sosyal medyayı kullanmaktadır. Sosyal medyaya çoğunlukla ve bazen de sadece mobil araçlar aracılığıyla erişim sağlamaktadırlar. Sosyal medyada günde ortalama 2 saat 43 dakika geçirmektedirler. En çok kullandıkları platformların başında YouTube gelmektedir. Öte yandan Pinterest ve Tumblr'ı daha az; Vine ve Instagram'1 daha çok kullanmaktadırlar. \%62'si Periscope'u ve \%34'ü ise LinkedIn'i hiç duymadığını belirtmiştir. Bireyler arası iletişim için ise Facebook Messenger tercih etmektedirler Whisper, Yik Yak ve Secret gibi aplikasyonlar Z Kuşağı arasında popülerdir (Pruett, 2018; Wheeler, 2018; Williams, 2018). Öte yandan sosyal medyadaki "hikaye" formatının başladığı yer olan Snapchat sitesi daha çok Z kuşağı tarafından kullanılmakta, X ve Y kuşağı tarafından çok tercih edilmemektedir (Sproutsocial, 2019). "Hikaye" formatındaki içerikler oluşturulduktan 24 saat kaybolmaları özelliğiyle ön plana çıkmış ve sosyal medyadaki hızlı tüketimin en önemli göstergelerinden biri olmuştur. Daha sonraları bazı platformlarda kaydedilme ve uzun süre saklanma özelliği gelse de, "hikaye" formatındaki içeriklerin çoğu 24 saatte silinmeye devam etmektedir. Snapchat sitesinin başlatmış olduğu bu format daha sonra farklı platformlar tarafından kullanılmaya da başlanmıştır. Bu formatı ilk adapte eden sosyal medya sitesi Instagram olup, kullanıcı profiline bakıldığında bu siteyi en çok kullanan kuşağın da yine Z kuşağı olduğu görülmektedir (Sproutsocial, 2019). Sosyal medyada takma isimde hesaplar kullanmayı tercih etmektedirler (Sehl, 2018). Kendilerine eğlenceli içerik ile yenilikçi ürün ve fikirler sunan, kendilerini değerli hissettiren markaları takip etmektedirler (Williams, 2018). \%65'i markaları sosyal medya üzerinden takip ettiğini, \%74’ü ise sosyal medya üzerinden indirimleri, kullanıcı yorumlarını ve kullanım kılavuzu tarzındaki videoları takip ettiğini ifade etmektedir. Her ne kadar sosyal medyanın zarardan çok yarar sağladığını düşünseler de Z Kuşağı temsilcilerinin \%41'i sosyal medyanın kendilerini stresli, üzgün ve depresif bir ruh haline soktuğunu ifade etmiştir (Business Wire, 2018; McAteer, 2018).

Araştırmalar ve kullanıcı istatistikleri Z kuşağının sosyal medya kullanımının ve beklentilerinin diğer kuşaklardan farklı olduğunu ortaya koymaktadır. Bu bilgi pazarlama yöneticileri için oldukça önemli olup, sosyal medyada farklı yaş gruplarına ulaşmak için farklı stratejiler yürütmenin gerekliliğini ortaya koymaktadır. Aşağıdaki tabloda Z Kuşağının sosyal medya kullanım motivasyonlarına dair bilgilere yer verilmiştir (Beer, 2018; Yücel Güngör, 2018). 
Doğan, S., Erkan, İ. / Journal of Yasar University, 2019, 14 (Special Issue), 147-155

Tablo 2. Z Kuşağının Sosyal Medya Kullanım Motivasyonları

Motivasyon

Boş zaman değerlendirmek

Eğlenceli ve komik içerik bulmak

Arkadaşlarının ne yaptığını takip etmek

Haberler ve olayları takip etmek

Fotoğraf ve video paylaşmak

Diğer insanlarla bağlantı kurmak

Pek çok arkadaş sosyal medyada olduğu için

\author{
Z kuşağı (\%) \\ 45 \\ 42 \\ 39 \\ 35 \\ $-$
}

Z kuşağı bireylerinin sosyal medya algıları daha önceki araştırmacıların da dikkatini çekmiştir. Egüz ve Kesten (2018) bu algıları 6 kategoriye ayırmış; öğrencilerin sosyal medyayı (1) yol gösteren ve bilgiye ulaştıran bir kaynak olarak, (2) bağımlılık yaratan bir unsur olarak, (3) gerçeği yansıtan ve etkileşimi sağlayan bir araç olarak, (4) zaman kaybı olarak, (5) gereksinim olarak, (6) gizlenme alanı olarak algıladığını ifade etmiştir. Birinci kategoride karşılaşılan metaforlardan bazıları (sosyal medya hakkında düşünülen ifadeler) "dünya", "okyanus", "gazete"; ikinci kategoride karşılaşılan metaforlardan bazıları "uyuşturucu", "sigara", "hapishane"; üçüncü kategoride karşılaş1lan metaforlardan bazıları "arkadaş", "ayna", "hayat"; dördüncü kategoride karşılaşılan metaforlardan bazıları "hırsız", "canavar", "düşman"; beşinci kategoride karşılaşılan metaforlardan bazıları "güneş" ve "uyku”; son kategoride karşılaşılan metafor ise "maskeli balo" olarak tespit edilmiştir.

Başka bir çalışmada ise öğretmen adaylarının sosyal medya algıları incelenmiş, bulgular 4 kategoride toplanmıştır: zarar, paylaşım, hem iyi hem kötü, eğlence (Erdem vd., 2017). "Zarar” kategorisinde karşılaşılan metaforlardan bazıları "bataklık”, "çöplük”, "kara delik"; "paylaşım” kategorisinde karşılaşılan metaforlardan bazıları "arkadaş", "büyük bir aile", "gökyüzü"; "hem iyi hem kötü” kategorisinde karşılaşılan metaforlardan bazıları "labirent”, "zaman tüneli”, "kredi kartı"; son olarak eğlence kategorisinde karşılaşılan metaforlardan bazıları ise "dondurma”, “oyun”, "çekirdek” olarak gözlemlenmiştir.

Onursoy (2017) ise çalışmasında sosyal medya hakkındaki algıları olumlu ve olumsuz olmak üzere iki kategoriye ayırmıştır. Olumlu kategorisinde yer alan metaforlardan bazıları "çeşitlilik", "globallik", "hız”, "mutluluk”, "mizah", "arkadaşlık" ve "bilgi”" iken olumsuz kategorisinde yer alan metaforlardan bazıları "bağımlılık", "gerçeklikten kopma", "gizlenme", "propaganda", "zaman kaybı", "tehlike ve korku”, "stres", "yalnızlık" ve "çatışma" olarak ifade edilmiştir.

Sosyal medyanın Z kuşağı tarafından nasıl algılandığı farklı alanlardan araştırmacılar için önemli bir araştırma sorusu olmuştur. Ancak bu soru özellikle pazarlama yöneticileri için çok büyük önem arz etmektedir. Çalışmada, bu sebeple Z kuşağı ile bir metafor analizi gerçekleştirmiş ve bu kuşağın sosyal medya kavramına yönelik algıları belirlenmeye çalışılmıştır.

\title{
3. Araştırma Metodolojisi
}

\subsection{Araștırmanın Yöntemi}

Bu araștırmada, Turizm Fakültesi öğrencilerinin "sosyal medya” kavramına yönelik metaforik düșünme durumlarını belirlemek için nitel araştırma desenlerinden "olgu bilim” kullanılmıştır. Olgu bilim (fenomenoloji) deseni, farkında olunan ama derinlemesine ve ayrıntılı bir anlayışa sahip olunmayan olgulara odaklanmaktadır. Olgu bilim, anlamı tam kavranamayan olguları araştırmayı amaçlayan çalışmalar için uygun bir araştırma zemini oluşturmaktadır. Birçok araştırmada metaforların nitel veri toplama aracı olabileceği ve onları güçlü ve zengin bulgular elde etmede kullanılabileceği belirtilmektedir (Özbuğutu, 2018; Kalaycı ve Yoğun, 2018; Sezgin vd., 2017; Ekici, 2016; Korkut ve Keskin, 2016; Kodan Çetinkaya, 2014; Kaya, 2013; Yazıcı, 2013; Kalyoncu, 2012). Araştırma, var olan durumun olduğu gibi ortaya konmasını amaçladığından betimsel nitelik taşımaktadır.

\subsection{Araştırmanın Amacı ve Soruları}

$\mathrm{Bu}$ araştırmada turizm fakültesinde lisans eğitimi alan öğrencilerin, "sosyal medya" ile ilgili algılarının metaforlar aracılığıyla belirlenmesi amaçlanmıştır. Bu amaç doğrultusunda aşağıdaki araştırma soruları belirlenmiştir:

1- Z Kuşağı "sosyal medya" kavramına dair hangi metaforları geliştirmiştir?

2- Bu metaforlar ortak özellikleri bakımından hangi kavramsal kategoriler altında toplanmaktadır?

\section{3. Çalışma Grubu}

Zaman kısıtı nedeniyle araştırma evreninde yer alan tüm puanlamaların toplanması zor olduğundan araştırmada Tesadüfi Olmayan Örnekleme yöntemlerinden Kolayda Örnekleme tercih edilmiştir. Kolayda örnekleme, ana kütle içerisinden seçilecek örnek kesimin araştırmacının yargılarınca belirlendiği tesadüfî olmayan örnekleme yöntemidir. Kolayda örneklemede veriler, ana kütleden en kolay, hızlı ve ekonomik şekilde toplanmaktadır (Çeliköz ve Erişen, 2017, Fırat ve 
Aydın, 2016; Gülertekin Genç vd., 2016; Haş1loğlu vd., 2015). Bu doğrultuda araştırmanın çalışma grubunun 2018-2019 eğitim-öğretim yılının bahar yarıyılında Ondokuz Mayıs Üniversitesi Turizm Fakültesi Turizm İşletmeciliği 2 ., 3 . ve 4. sınıfta öğrenim gören 156 öğrenci oluşturmaktadır. Verilerin toplanması için belirlenen tarihte okulda bulunan 99 öğrenci ile araştırma gerçekleştirilmiştir.

\subsection{Verilerin Toplanması}

Araştırmanın uygulamasından önce öğrencilere metafor tekniği hakkında bilgi verilmiştir. Daha sonra öğrencilere "Sosyal medya ...... gibidir, çünkü......" cümlesini tamamlamaları istenmiştir. Cümlede "çünkü" kelimesine yer verilerek öğrencilerin, geliştirdikleri metaforlar için bir gerekçe sunmaları istenmiştir. Öğrencilerden sadece tek bir metafor üzerinde yoğunlaşarak 45 dakikalık ders süresi içerisinde bir kompozisyon yazmaları istenmiştir. Öğrencilerin oluşturdukları bu metaforlar araştırmanın birincil veri kaynağını oluşturmaktadır.

\subsection{Verilerin Analizi}

Araştırmada, veriler "içerik analizi” ile analiz edilmiştir. İçerik analizin amacı, ham verilerin okuyucunun rahatlıkla anlayabileceği bir biçimle sunulmasıdır. İçerik analizinde, veriler ayrıntılı bir şekilde işlenerek fark edilemeyen kavram ve temalar keşfedilmektedir. Toplanan verilerin önce kavramsallaştırılması, daha sonra da bunların anlamlı ve mantıklı bir biçimde düzenlenmesi, buna bağlı olarak veriyi açıklayan temaların saptanması gerekmektedir (Özbuğutu, 2018; Arslan ve Zengin, 2016; Sezgin vd., 2017). Araştırmada elde edilen verilerinin analizinde literatürdeki farklı çalışmalarda belirtilen yol izlenmiştir (Köroğlu vd., 2018; Şahin vd., 2018; Karaçam ve Aydın, 2014; Kaya, 2014; Çulha Özbaş ve Aktekin, 2013; Çulha Özbaş, 2012). Bunun için öncelikle;

1- Metaforlar belirlenmiş, ayıklanmış ve kodlanmıştır.

2- Metaforlardan örnek metaforlar derlenerek, ana metaforlar belirlenmiştir.

3- Ana metaforlar kendi aralarında gruplandırılmıştır.

Metaforların belirlenmesi, ayıklanması ve kodlanması aşamasında öğrencilerin yazdıkları metinler 1'den 99'a kadar numaralandırılmıştır. Ardından cinsiyet için k=kadın ve e=erkek şeklinde kodlama yapılmıştır.

Metaforlardan derlenerek ana metaforların belirlenmesi aşamasında 99 öğrencinin geliştirdiği 79 metafor incelenmiş ve bunların arasından 26'sı tam anlaşılamadığı ve herhangi bir mantıksal gerekçeye dayandırılamadığı için araştırma kapsamı dışında bırakılmıştır. Geriye kalan 53 metaforun ortak yönleri üzerinde durularak ana metaforlar belirlenmiş ve bu ana metaforları en güzel temsil ettiği düşünülen örnekler seçilerek araştırma içinde sunulmuştur.

Ana metaforların kendi aralarında gruplandırılması aşamasında ise öğrenciler tarafından üretilen metaforlar, ortak özellikleri bakımından iki farklı kavramsal kategori altında toplanmıştır. Bulgular kısmında bu metaforlar ayrıntılı şekilde açıklanmaya çalışılmıştır.

\subsection{Geçerlik ve Güvenilirlik}

Nitel araştırmada güvenirliğini arttırmak için araştırmacıların bazı önlemler almaları önerilmektedir. Bu önlemler daha çok, araştırmada kullanılan stratejilerin neden/nasıl kullanıldığının belirgin hale getirilmesi ve bu şekilde diğer araştırmacıların bu stratejileri benzer bir biçimde kullanabilmesine olanak tanıması ile ilişkilidir. Bu noktada araştırmacı izlediği aşamaları ayrıntılı ve açık bir biçimde rapor ettiği takdirde araştırmasının dış güvenirliği, araştırma sonuçlarını kendi tercih ve yönelimlerine göre biçimlendirmediğini okuyucuya aktardığı takdirde ise araştırmanın iç güvenilirliği konusunda önemli adımlar atmış olacaktır. Yine araştırma sonucu rapor edilirken, bulguların bir bölümünün orijinalliği bozulmaksızın verilmesi araştırmanın iç güvenilirliğini önemli bir şekilde yükseltecek önlemlerdendir (Ekici ve Akdeniz, 2018; Ayyıldız, 2016; Babacan, 2014; Eren vd., 2014; Kodan Çetinkaya, 2014; Çulha Özbaş, 2012). Bu araştırmada da metaforların belirlenme süreci ayrıntılı bir şekilde betimlenmiş ve araştırmanın bulguları kısmında katılımcıların ifadelerinden birebir örnekler sunulmuştur.

\section{Bulgular ve Değerlendirme}

Araştırmaya katılan ve geliştirdiği metaforlar araştırma kapsamına alınan 71 Turizm İşletmeciliği öğrencisinin 32'si kız, 23'ü erkektir. Öğrencilerin “sosyal medya” kavramına yönelik olarak geliştirdikleri metaforlar Tablo 3'de sunulmaktadır.

Tablo 3. Sosyal Medya Kavramına Yönelik Geliştirilen Metaforlar

\begin{tabular}{|c|c|c|c|c|c|c|c|}
\hline \multirow[t]{2}{*}{ Sira No } & \multirow[t]{2}{*}{ Metafor Adı } & \multicolumn{2}{|c|}{$\begin{array}{c}\text { Metaforu } \\
\text { Geliştiren } \\
\text { Öğrenci } \\
\text { Sayısı }\end{array}$} & \multirow[t]{2}{*}{ Sira No } & \multirow[t]{2}{*}{ Metafor Adı } & \multicolumn{2}{|c|}{$\begin{array}{c}\text { Metaforu } \\
\text { Geliştiren } \\
\text { Öğrenci } \\
\text { Sayısı }\end{array}$} \\
\hline & & $\mathbf{n}$ & $\%$ & & & $\mathbf{n}$ & $\%$ \\
\hline 1 & Kuyu & 5 & 6,3 & 28 & Sanal Silah & 1 & 1,3 \\
\hline
\end{tabular}


Doğan, S., Erkan, İ. / Journal of Yasar University, 2019, 14 (Special Issue), 147-155

\begin{tabular}{|c|c|c|c|c|c|c|c|}
\hline 2 & Dünya & 4 & 5,0 & 29 & İp & 1 & 1,3 \\
\hline 3 & Hayat/Yaşam & 3 & 3,8 & 30 & İllüzyon & 1 & 1,3 \\
\hline 4 & Alternatif yaşam/hayat & 2 & 2,5 & 31 & Kedi & 1 & 1,3 \\
\hline 5 & Sigara & 2 & 2,5 & 32 & Üniversite & 1 & 1,3 \\
\hline 6 & AVM & 2 & 2,5 & 33 & Lise & 1 & 1,3 \\
\hline 7 & Çı̆̆ & 2 & 2,5 & 34 & Kadın & 1 & 1,3 \\
\hline 8 & Girdap & 2 & 2,5 & 35 & Kamera & 1 & 1,3 \\
\hline 9 & Bulaşıcı hastalık & 2 & 2,5 & 36 & Balta girmemiş orman & 1 & 1,3 \\
\hline 10 & Bağ & 2 & 2,5 & 37 & Kiyafet & 1 & 1,3 \\
\hline 11 & Kol & 2 & 2,5 & 38 & Kötü arkadaş & 1 & 1,3 \\
\hline 12 & Makyaj & 2 & 2,5 & 39 & Kap1 & 1 & 1,3 \\
\hline 13 & Zehir & 1 & 1,3 & 40 & Öğretmen & 1 & 1,3 \\
\hline 14 & Kanser türü & 1 & 1,3 & 41 & Mayın tarlası & 1 & 1,3 \\
\hline 15 & Kitle imha silahı & 1 & 1,3 & 42 & Maske & 1 & 1,3 \\
\hline 16 & Sanal hapishane & 1 & 1,3 & 43 & Miknatis & 1 & 1,3 \\
\hline 17 & Alkol & 1 & 1,3 & 44 & Örümcek ağ1 & 1 & 1,3 \\
\hline 18 & Bukalemun & 1 & 1,3 & 45 & Oyuncak & 1 & 1,3 \\
\hline 19 & Beyin & 1 & 1,3 & 46 & Postane & 1 & 1,3 \\
\hline 20 & Boşluk & 1 & 1,3 & 47 & Süpermarket & 1 & 1,3 \\
\hline 21 & Çanta & 1 & 1,3 & 48 & Pembe gözlük & 1 & 1,3 \\
\hline 22 & Uyuşturucu & 1 & 1,3 & 49 & Yedi büyük günah & 1 & 1,3 \\
\hline 23 & Dolmakalem & 1 & 1,3 & 50 & Yakın arkadaş & 1 & 1,3 \\
\hline 24 & $\mathrm{Ev}$ & 1 & 1,3 & 51 & Okul & 1 & 1,3 \\
\hline 25 & Ebeveyn & 1 & 1,3 & 52 & Hava & 1 & 1,3 \\
\hline 26 & Oyun Park1 & 1 & 1,3 & 53 & $\mathrm{Su}$ & 1 & 1,3 \\
\hline 27 & İlaç & 1 & 1,3 & & & & \\
\hline
\end{tabular}

Tablo 3'de görüldüğü üzere Turizm İşletmeciliği öğrencilerinin sosyal medya kavramına yönelik geliştirmiş olduğu 53 geçerli metafor bulunmaktadır. Öğrencilerden 5'i sosyal medyayı kuyuya, 4'ü dünyaya, 3'ü ise hayat/yaşama benzetmiştir.

Öğrencilerin geliştirdiği metaforlar olumlu ve olumsuz olmak üzere iki grupta incelenmiş olup Tablo 4'de gösterilmiştir.

Tablo 4. Sosyal Medya Kavramına Yönelik Geliştirilen Olumlu ve Olumsuz Metaforlar

\begin{tabular}{|c|c|c|c|c|c|c|c|}
\hline \multirow[t]{2}{*}{ Sira No } & \multirow[t]{2}{*}{ Olumlu Metaforlar } & \multicolumn{2}{|c|}{$\begin{array}{c}\text { Metaforu } \\
\text { Geliştiren } \\
\text { Öğrenci } \\
\text { Sayısı }\end{array}$} & \multirow[t]{2}{*}{ Sira No } & \multirow[t]{2}{*}{ Olumsuz Metaforlar } & \multicolumn{2}{|c|}{$\begin{array}{c}\text { Metaforu } \\
\text { Geliştiren } \\
\text { Öğrenci } \\
\text { Sayısı }\end{array}$} \\
\hline & & $\mathbf{n}$ & $\%$ & & & $\mathbf{n}$ & $\%$ \\
\hline 1 & Dünya & 4 & 5,0 & 1 & Kuyu & 5 & 6,3 \\
\hline 2 & Hayat/Yaşam & 3 & 3,8 & 2 & Bulaşıcı hastalık & 2 & 2,5 \\
\hline 3 & Bağ & 2 & 2,5 & 3 & Girdap & 2 & 2,5 \\
\hline 4 & AVM & 2 & 2,5 & 4 & Kol & 2 & 2,5 \\
\hline 5 & Çı̆ & 2 & 2,5 & 5 & Makyaj & 2 & 2,5 \\
\hline 6 & Beyin & 1 & 1,3 & 6 & Sigara & 2 & 2,5 \\
\hline 7 & Ev & 1 & 1,3 & 7 & Alternatif yaşam/hayat & 2 & 2,5 \\
\hline 8 & Ebeveyn & 1 & 1,3 & 8 & Zehir & 1 & 1,3 \\
\hline 9 & Oyun Park1 & 1 & 1,3 & 9 & Sanal Silah & 1 & 1,3 \\
\hline 10 & Postane & 1 & 1,3 & 10 & İp & 1 & 1,3 \\
\hline 11 & Süpermarket & 1 & 1,3 & 11 & İllüzyon & 1 & 1,3 \\
\hline 12 & Yakın arkadaş & 1 & 1,3 & 12 & Kadin & 1 & 1,3 \\
\hline 13 & Kedi & 1 & 1,3 & 13 & Kamera & 1 & 1,3 \\
\hline 14 & Üniversite & 1 & 1,3 & 14 & Balta girmemiş orman & 1 & 1,3 \\
\hline 15 & Lise & 1 & 1,3 & 15 & Kiyafet & 1 & 1,3 \\
\hline 16 & Kap1 & 1 & 1,3 & 16 & Kötü arkadaş & 1 & 1,3 \\
\hline 17 & Öğretmen & 1 & 1,3 & 17 & Mayın tarlas1 & 1 & 1,3 \\
\hline 18 & Okul & 1 & 1,3 & 18 & Maske & 1 & 1,3 \\
\hline 19 & Oyuncak & 1 & 1,3 & 19 & Miknatıs & 1 & 1,3 \\
\hline & & & & 20 & Örümcek ağ 1 & 1 & 1,3 \\
\hline
\end{tabular}




\begin{tabular}{|l|l|c|c|}
\hline $\mathbf{2 1}$ & Uyuşturucu & 1 & 1,3 \\
\hline $\mathbf{2 2}$ & Dolmakalem & 1 & 1,3 \\
\hline $\mathbf{2 3}$ & Pembe gözlük & 1 & 1,3 \\
\hline $\mathbf{2 4}$ & Yedi büyük günah & 1 & 1,3 \\
\hline $\mathbf{2 5}$ & Kanser türü & 1 & 1,3 \\
\hline $\mathbf{2 6}$ & Kitle imha silahı & 1 & 1,3 \\
\hline $\mathbf{2 7}$ & Hava & 1 & 1,3 \\
\hline $\mathbf{2 8}$ & Su & 1 & 1,3 \\
\hline $\mathbf{2 9}$ & İlaç & 1 & 1,3 \\
\hline $\mathbf{3 0}$ & Sanal hapishane & 1 & 1,3 \\
\hline $\mathbf{3 1}$ & Alkol & 1 & 1,3 \\
\hline $\mathbf{3 2}$ & Bukalemun & 1 & 1,3 \\
\hline $\mathbf{3 3}$ & Boşluk & 1 & 1,3 \\
\hline $\mathbf{3 4}$ & Çanta & 1 & 1,3 \\
\hline
\end{tabular}

Tablo 4'de görüldüğü üzere Turizm İşletmeciliği öğrencilerinin sosyal medya kavramına yönelik geliştirmiş olduğu 53 geçerli metaforun 19'u olumlu, 34'ü olumsuz anlam içermektedir.

\section{Sonuç ve Öneriler}

$\mathrm{Bu}$ araştırmada Z kuşağının sosyal medya kavramına yönelik algılarını belirlemek amaçlanmıştır. Bu amaç doğrultusunda Turizm İşletmeciliği Bölümünde öğrenim gören 99 öğrenciden sosyal medya kavramına yönelik olarak bir metafor geliştirmeleri istenmiş ve toplamda 53 adet geçerli metafor elde edilmiştir. Metaforların çoğunlukla olumsuz anlam içerdiği görülmüştür.

Olumlu metaforlar ve içerdikleri anlamlar incelendiğinde sosyal medyanın hayatın kendisi olduğu, bir ebeveyn veya öğretmen gibi yeni şeyler öğrettiği, en yakın arkadaş gibi güzel anların paylaşıldığı bir mecra olduğu sonucu elde edilmiştir. Bu sonuçlar Egüz ve Kesten'in (2018) çalışmasında karşılaşılan olumlu bulgularla örtüşmektedir. Bahsedilen çalışmada sosyal medya yol gösteren ve bilgiye ulaştıran bir kaynak olarak, etkileşimi sağlayan bir araç olarak, ve gereksinim olarak görülmüş; "dünya”, “okyanus", “arkadaş”, "hayat”, "güneş" gibi metaforlarla tanımlanmıştır. Çalışmamızda bulunan olumlu metaforların öğretmen adaylarının sosyal medya algıları üzerine yapılan çalışmadaki olumlu metaforlarla da uyuştuğu görülmektedir (Erdem vd., 2017). Bu çalışmada katılımcılar sosyal medya kavramını “arkadaş”, "büyük bir aile”, "gökyüzü” gibi metaforlar ile eşleştirmiştir. Onursoy (2017) tarafından yapılan çalışmadaki olumlu metaforlar ile çalışmamızdaki olumlu metaforlar kıyaslandığında ise sadece "arkadaşlık" ve "bilgi”" gibi kavramların örtüştüğü anlaşılmaktadır. Onursoy’un (2017) çalışmasında yer olan olumlu metaforlardan bazıları (örneğin, "çeşitlilik", "globallik", "hız”, “mutluluk", "mizah”) bu çalışmada gözlemlenmemiştir. Bu durumun muhtemel sebeplerinden birinin kullanılan araştırma yöntemindeki farklılık olduğu düşünülmektedir. Onursoy (2017) çalışmasını grafik düzenleme yazılımı (Adobe Photoshop) bilgisine sahip katılımcılar ile gerçekleştirmiş ve mülakatlar öncesinde katılımcılardan sosyal medyaya dair duygu ve düşüncelerini temsil eden resimler istemiştir. Bu çalışmada ise görseller kullanılmamış, katılımcılardan sadece sözlü yanıtlar vermesi talep edilmiştir.

Olumsuz metaforlar ve içerdikleri anlamlar incelendiğinde ise sosyal medyanın dipsiz bir kuyu gibi içine gireni hapsettiği, bulaşıcı bir hastalık gibi kısa sürede her yere ve herkese bulaştığı, insanların olduğundan farklı göründüğü bir mecra olduğuna dair sonuçlar elde edilmiştir. Bu sonuçlar Egüz ve Kesten'in (2018) çalışmasında karşıllaşılan olumsuz bulgularla benzeşmektedir. Bahsedilen çalışmada sosyal medyanın bağımlılık yaratan bir unsur olarak algılanması üzerinde durulmuş; sosyal medya "uyuşturucu", "sigara", "hapishane" gibi metaforlarla tanımlanmıştır. Egüz ve Kesten'in (2018) çalışmasında öne çıkan olumsuz bulgulardan "zaman kaybı" ve "gizlenme alanı” metaforlarına bu çalışmada rastlanmamış; ancak "kanser türü", "kitle imha silahı” ve "mayın tarlası" gibi daha farklı tanımlamalara rastlanmıştır. Bu bulgular öğretmen adaylarının sosyal medya algılarının incelendiği bir başka çalışmada bulunan "zarar" kategorisi ile benzerlik göstermektedir (Erdem vd., 2017). Bahsi geçen çalışmada araştırmacılar "bataklık”, "çöplük”, "kara delik" gibi ifadelerle karşılaşmış ve bu metaforları "zarar" başlığı altında kategorize etmişlerdir. Çalışmamızda rastlanan olumsuz bulgular Onursoy’un (2017) çalışmasında yer alan olumsuz bulgularla karşılaştırıldığgnda ise yine "bağımlılık" metaforu ön plana çıkmaktadır. Bu çalışmada Z kuşağının sosyal medyayı "sigara", "alkol" ve "uyuşturucu" gibi metaforlar ile tanımladığı ve sosyal medyanın bağımlılık yapan yönüne dikkat çektiği görülmektedir. Benzer şekilde Onursoy'un (2017) çalışmasında da "bağımlılık” metaforu ile karşılaşıllmıştır. Çalışmada ön plana çıkan "sağlık endişesi”, "tehlike ve korku" gibi olumsuz metaforlar da yine bu çalışmada karşılaşılan "sigara", "alkol", ve "uyuşturucu" metaforları ile paralellik göstermektedir. Onursoy’un (2017) çalışmasında karşılaşılan diğer bir olumsuz metafor olan "zaman kaybı" ifadesine Egüz ve Kesten'in (2018) çalışmasında da bire bir aynı şekilde rastlanmış, ancak yukarıda da bahsedildiği gibi bu çalışmada karşılaşılmamıştır.

Çalışmada tespit edilen bulgular araştırmacılar için oldukça büyük önem arz etmektedir. Şu anki Z kuşağı gelecekte tüketicilerin çoğunluğunu oluşturacağı için onlar üzerinde çok fazla çalışma yapılmaktadır. Bu araştırmada metafor analizi ile elde edilen bulgular, ileride yapılacak çalışmalar için bir temel teşkil edebilecektir. Öte yandan, pazarlama yöneticileri için Z kuşağı hem günümüzde hem de gelecekte önemli bir pazar oluşturmaktadır. Bu kuşağın sosyal medya 
Doğan, S., Erkan, İ. / Journal of Yasar University, 2019, 14 (Special Issue), 147-155

hakkındaki algıları, sosyal medya pazarlamasına başvuran ya da başvuracak olan yöneticiler için çok önemli ipuçları sağlamaktadır. Araştırma süresince ihtiyacını gözlemlediğimiz ve tavsiye edeceğimiz noktalardan biri de sosyal medyanın doğru ve detaylı şekilde anlatıldığı derslerin müfredata eklenmesi gerekliliğidir. Sosyal medya ajanslarından yetkililerin okullara davet edilmesi, ve konferanslar vermeleri sağlanarak öğrencilerin sosyal medyaya yönelik algılarının geliştirilmesine olanak tanınmalıdır. Bu çalışma hem pazarlama araştırmacıları hem de pazarlama yöneticileri için önemli katkılar sunmakla beraber, bazı araştırma kısıtları barındırmaktadır. Bu kısıtlardan birisi katılımcı sayısıdır. Çalışmamız sadece bir devlet üniversitesinin Turizm Fakültesi bünyesindeki Turizm İşletmeciliği Bölümüne kayıtlı 99 öğrenci ile gerçekleştirilmiştir. İleride yapılacak olan araştırmalarda üniversite, bölüm ve öğrenci sayıları artırılarak daha genellenebilir sonuçlar elde edilebilir. Ayrıca fakülte ve bölümler arası karşılaştırmalar yapılarak pazarlama yöneticilerine daha kapsamlı sonuçlar ve öneriler sunulabilir. 


\section{KAYNAKÇA}

Arslan, A. ve Zengin, R. (2016). Fen Bilgisi Öğretmen Adaylarının Küresel Isınma Kavramına İlişkin Algılarının Metafor Analizi Yoluyla İncelenmesi, Journal of Academic Science Studies, 44, 453-466.

Artemova, A. (2018). Engaging Generation Z Through Social Media Marketing Case: Hurja Media Oy, Bachelor's Thesis, Business Management South-Eastern Finland University of Applied Sciences, https://www.theseus.fi/bitstream/handle/10024/142658/Artemova_Alexandra.pdf?sequence=1\&isAllowed=y

Ayyıldız, T. (2016). Üniversite Öğrencilerinin Dans Kavramına Yönelik Metaforik Algılarının Analizi, Gaziantep Üniversitesi Spor Bilimleri Dergisi, 1(2), 13-25.

Babacan, E. (2014). AGSL Öğrencilerinin Müzik Kavramına İlişkin Algıları: Metafor Analizi, Ĕgitim ve Öğretim Araştırmaları Dergisi, 3(1), 124-132.

Barutçu, S., \& Tomaş, M. (2013). Sürdürülebilir Sosyal Medya Pazarlaması ve Sosyal Medya Pazarlaması Etkinliğinin Ölçümü. Journal of Internet Applications \& Management/Internet Uygulamaları ve Yönetimi Dergisi, 4(1).

Beer, C. (2018). Reasons for Using Social Media by Generation, Global Web Index, Erişim adresi: https://blog.globalwebindex.com/chart-of-the-day/reasons-for-social-

media/?utm_campaign=Chart $\% 20$ of $\% 20$ the $\% 20$ Day\&utm_source=hs_email\&utm_medium=email\&utm_content= 62891161\&_hsenc=p2ANqtz-

9iKUu8P20GGaAuk0oNyl0mPZjToW3XJstExTs4WAOorjYYUoVMYTIPwW6ZZClwgJD9Lx9zgMEjNM70Qj Rdau8JgjhV3w\&_hsmi=62891161 Erişim tarihi: 15.10 .2019$.

Berkup, S. B. (2014). Working with generations X and Y in generation Z period: Management of different generations in business life. Mediterranean Journal of Social Sciences, 5(19), 218.

Business Wire. (2018). 34\% of Generation Z Social Media Users Have Quit Social Media Entirely, Erişim adresi: https://www.businesswire.com/news/home/20180305006051/en/34-Generation-Social-Media-Users-Quit-Social Erişim tarihi: 15.10 .2019 .

Çeliköz, M. ve Erişen, Y. (2017). EPÖ Alanında Görev Yapan Eğitim Bilimcilerin Yapılandırmacılıkla İlgili Görüşleri: Bir Karma Yöntem Araştırması, Ĕgitim ve Öğretim Araştırmaları Dergisi, 6(2), 286-304.

Çetin, C., \& Karalar, S. (2016). X, y ve z kuşağı öğrencilerin çok yönlü ve sınırsız kariyer algıları üzerine bir araştırma. Yönetim Bilimleri Dergisi, 14(28), 157-197.

Çulha Özbaş, B. (2012). "Sosyal Bilgiler Öğretmeni Olarak, Ben Kimim?” Sosyal Bilgiler Öğretmenlerinin Mesleki Kimliklerine Yönelik Görüşlerinin Metafor Analizi Yoluyla İncelenmesi, Turkish Studies - International Periodical For The Languages, Literature and History of Turkish or Turkic, 7(2), 821-838.

Çulha Özbaş, B. ve Aktekin, S. (2013). Tarih Öğretmen Adaylarının Tarih Öğretmenliğine İlişkin İnançlarının Metafor Analizi Yoluyla İncelenmesi, Eğitimde Kuram ve Uygulama Dergisi, 9(3), 211-218.

Egüz, Ş. ve Kesten, A. (2018). Sosyal bilgiler öğretmenliği öğrencilerinin sosyal medya algılarının metafor yoluyla belirlenmesi, Cumhuriyet International Journal of Education, 7(3), 219-240.

Ekici, G. ve Akdeniz, H. (2018). Öğretmen Adaylarının "Sınıfta Disiplin Sağlamak" Kavramına İlişkin Algılarının Belirlenmesi: Bir Metafor Analizi Çalışması, Dicle Üniversitesi Ziya Gökalp Eğitim Fakültesi Dergisi, 33, $26-37$.

Ekici, G. (2016). Biyoloji Öğretmeni Adaylarının Mikroskop Kavramına İlişkin Algılarının Belirlenmesi: Bir Metafor Analizi Çalışması, Ahi Evran Üniversitesi Kırşehir Ĕ̌itim Fakültesi Dergisi, 17(1), 615-636.

Erdem, A., Alkan, M.F. and Erdem, Ş. (2017) Öğretmen Adaylarının Sosyal Medya Kavramına İlişkin Algıları. Karaelmas Ĕgitim Bilimleri Dergisi, 5(2).

Eren, F., Çelik, İ. ve Aktürk, A.O. (2014). Ortaokul Öğrencilerinin Facebook Algısı: Bir Metafor Analizi, Kastamonu Ĕ̆itim Dergisi, 22(2), 635-648.

Fırat, A. ve Aydın, A. E. (2016). Hedonik ve Faydacı Alışveriş Davranışı Üzerine Bir Araştırma, Uluslararası Sosyal Araştırmalar Dergisi, 9(43), 1840-1846.

Global Web Index. (2018). What You Need to Know about Generation Z, Erişim adresi: https://www.globalwebindex.com/reports/generation-z Erişim tarihi: 15.10.2019.

Golovinski, M. S. (2011). Event 3.0: How Generation Y \& Z are Re-shaping the Events Industry. Lulu. com.

Gülertekin Genç, S., Genç, V. ve Gümüş, M. (2016). Otel İşletmelerinde Duygusal Zekanın İş Stresi ve İş Yaşam Dengesi Üzerindeki Etkisi, Batman Üniversitesi Yaşam Bilimleri Dergisi, 6(2/1), 97-112.

Haşıloğlu, S. B., Baran, T. ve Aydın, O. (2015). Pazarlama Araştırmalarındaki Potansiyel Problemlere Yönelik Bir Araştırma: Kolayda Örnekleme ve Sıklık İfadeli Ölçek Maddeleri, Pamukkale Işsletme ve Bilişim Yönetimi Dergisi, 2(1), 19-28.

Kalaycı, S. ve Yoğun, C. (2018). Ortaokul Öğrencilerinin “Alyuvar”, “Akyuvar” ve “Kan Pulcukları” Kavramları Hakkındaki Algılarının Metaforlar Yoluyla İncelenmesi, OPUS Uluslararası Toplum Araştırmaları Dergisi, 8(14), 188-216.

Kalyoncu, R. (2012). Görsel Sanatlar Öğretmeni Adaylarının “Öğretmenlik” Kavramına İlişkin Metaforları, Mustafa Kemal Üniversitesi Sosyal Bilimler Enstitüsü Dergisi, 9(20), 471-484.

Karaçam, S. ve Aydın, F. (2014). Ortaokul Öğrencilerinin Teknoloji Kavramına İlişkin Algılarının Metafor Analizi, Gaziantep Üniversitesi Sosyal Bilimler Dergisi, 13(2), 545-572.

Kaya, M.F. (2013). Sosyal Bilgiler Öğretmen Adaylarının “Küresel Isınma” Kavramına Yönelik Metafor Algıları, Doğu Coğrafya Dergisi, 29, 117-134. 
Kodan Çetinkaya, S. (2014). Öğrencilerinin Kendi Mesleklerine İlişkin Algılarının Metafor Analizi ile İncelenmesi, Pamukkale Üniversitesi Ë̆itim Fakültesi Dergisi, 36, 137-150.

Korkut, A. ve Keskin, İ. (2016). Üniversite Öğrencilerinin Kariyer Algıları: Metaforik Bir Analiz Çalışması, Mustafa Kemal Üniversitesi Sosyal Bilimler Enstitüsü Dergisi, 13(33), 194-211.

Köroğlu, Ö., Ulusoy Yıldırım, H. ve Avcıkurt, C. (2018). Kültürel Miras Kavramına İlişkin Algıların Metafor Analizi Yoluyla İncelenmesi, Turizm Akademik Dergisi, 5(1), 98-113.

McAteer, O. (2018). Gen Z quitting Social Media in droves bevause i makes them unhappy, study finds, Erişim adresi: https://www.prweek.com/article/1459149/gen-z-quitting-social-media-droves-makes-unhappy-study-finds Erişim tarihi: 15.10 .2019 .

Onursoy, S. (2017). Sosyal medya tüketicilerinin derin metaforları: sosyal medya üzerine bir ZMET çalışması. 1. Uluslararası İletişimde Yeni Yönelimler Konferansı, İstanbul, 79-90.

Özbuğutu, E. (2018). Fen Bilgisi Öğretmen Adaylarının Evrim Kavramına İlişkin Metaforik Algıları, Academia Ĕ̆itim Araştırmaları Dergisi, 31(1), 28-43.

Özkan, M. ve Solmaz, B. (2015). Mobile Addiction of Generation Z and Its Effects. Procedia - Social and Behavioral Sciences , 205, 92-98.

Sarıtaş, E., \& Barutçu, S. (2016). Tüketici Davranışlarının Analizinde Kuşaklar: Sosyal Medya Kullanımı Üzerinde Bir Araştırma. Pamukkale Journal of Eurasian Socioeconomic Studies, 3(2), 1-15.

Pruett, M. (2018). Gen Z's Favorite Social Networks: YouTube, Instagram, Snapchat, Erişim adresi: https://www.criteo.com/insights/gen-Z-social-media/ Erişim tarihi: 15.10.2019.

Sehl, K. (2018). Everything Social Marketers Need to Know About Generation Z, Erişim adresi: https://blog.hootsuite.com/generation-Z-statistics-social-marketers/ Erişim tarihi: 15.10.2019.

Sezgin, F., Koşar, D., Koşar, S. ve Er, E. (2017). Öğretmenlerin Öğrenciye Yönelik Metaforlarının Belirlenmesine İlişkin Nitel Bir Araştırma, Hacettepe Üniversitesi Ĕ̈itim Fakültesi Dergisi, 32(3), 600-611.

Singh, A. (2014). Challenges and Issues of Generation Z. IOSR Journal of Business and Management, 16 (7), 59-63.

Sproutsocial (2019). Erişim adresi: https://sproutsocial.com/insights/new-social-media-demographics/ Erişim tarihi: 14.10.2019.

Şahin, S., Tezcan, A. E. ve Bekçi, M. (2018). Yerli Turistlerin Türkiye, İstanbul, Turizm ve Turist Rehberi ile İlgili Metaforlar1, Turizm Akademik Dergisi, 5(1), 251-264.

Tetik, N. (2006). Türkiye’de Profesyonel Turizm Rehberliği ve Müşterilerin Turist Rehberlerinden Beklentilerinin Analizi: Kuşadası Örneği , Yüksek Lisans Tezi, Balıkesir Üniversitesi Sosyal Bilimler Enstitüsü, Balıkesir.

Wheeler, J. (2018). Three key differences between Gen Z and Millennial social media habits, Erişim adresi: https://www.genzinsights.com/three-key-differences-between-gen-z-and-millennial-social-media-habits Erişim tarihi: 15.10 .2019 .

Williams, V. (2018). Where is Gen $\mathrm{Z}$ Spending Time on Social Media, Erişim adresi: https://www.ignitesocialmedia.com/social-media-strategy/gen-z-spending-time-social-media/ Erişim tarihi: 15.10.2019.

Yazıcı, Ö. (2013). Coğrafya Öğretmenlerinin “Çevre” Kavramına İlişkin Algıları: Bir Metafor Analizi Çalışması, Journal of Academic Social Science Studies, 6(5), 811-828.

Yücel Güngör, M. (2018). Kuşakların Sosyal Medya Kullanımının Yiyecek İçecek Isşletmesi Tercihleri Üzerine Etkisi, Doktora Tezi, Adnan Menderes Üniversitesi Sosyal Bilimler Enstitüsü, Aydın. 